\title{
Not Known if Testing Was Performed
}

National Cancer Institute

\section{Source}

National Cancer Institute. Not Known if Testing Was Performed. NCI Thesaurus. Code C160290.

An indication that it is not known what tests were performed during the study. 